\title{
Physical property comparison of 11 soft denture lining materials as a function of accelerated aging
}

\author{
E. R. Dootz, CDT, ${ }^{a}$ A. Koran, DDS, ${ }^{b}$ and R. G. Craig, $\mathbf{P h D}^{\mathrm{c}}$ \\ School of Dentistry, The University of Michigan, Ann Arbor, Mich. \\ Soft denture-lining materials are an important treatment option for patients who \\ have chronic soreness associated with dental prostheses. Three distinctly diff erent \\ types of materials are generally used. These are plasticized polymers or copoly- \\ mers, silicones, or polyphosphazene fluoroelastomer. The acceptance of these \\ materials by patients and dentists is variable. The objective of this study is to \\ compare the tensile strength, percent elongation, hardness, tear strength, and tear \\ energy of eight plasticized polymers or copolymers, two silicones, and one poly- \\ phosphazene fluoroelastomer. Tests were run at 24 hours after specimen prepara- \\ tion and repeated after 900 hours of accelerated aging in a Weather-Ometer \\ device. The data indicated a wide range of physical properties for soft denture- \\ lining materials and showed that accelerated aging dramatically affected the \\ physical and mechanical properties of many of the elastomers. No soft denture \\ liner proved to be superior to all others. The data obtained should provide clini- \\ cians with useful information for selecting soft denture lining materials for \\ patients. (J Prosthet Dent 1993;69:114-9.)
}

$\mathrm{T}_{\mathrm{h}}$ esthetics, comfort, and function. Unfortunately, the health of the supporting tissues may be adversely affected by high stress concentrations during function. ${ }^{1,2}$ Chronic soreness is a significant problem for denture patients with diabetes or other debilitating diseases and for many geriatric patients. ${ }^{3,4}$ In addition, patients with heavy bruxing or clenching habits may suffer the same consequence. The soft denture-bearing mucosa is confined between the hard denture base and bone. During function, considerable damage can be done to the supporting tissues resulting in chronic soreness, pathologic changes, and bone loss. The use of soft lining materials is designed to distribute functional and nonfunctional stresses more evenly and to have a dampening effect because of elastic behavior. These properties make soft denture lining materials useful for treating patients with (1) ridge atrophy or resorption, (2) bony undercuts, (3) bruxing tendencies, (4) congenital or acquired oral defects requiring obturation, (5) xerostomia, and (6) dentures opposing natural dentition in the opposing arch. ${ }^{4}$

Unfortunately, no products are available that will remain serviceable for extended periods of time..$^{5-10}$ At best, the

Presented in part before the International Association of Dental Research, Acapulco, Mexico.

Supported by National Institutes of Health-National Institute of Dental Research grant No. DE 09296.

aSenior Research Associate, Biologic and Materials Science Department.

brofessor of Dentistry, Prosthodontics Department.

'Marcus L. Ward Professor of Dentistry, Biologic and Materials Science Department.

$10 / 1 / 42440$ available products are considered temporary expedients; their service expectancy does not compare with that of the hard denture base. Failures are associated with poor physical and mechanical properties that foul the lining materials by fungal and bacterial growth and bond poorly to denture base materials. ${ }^{5}$

The purpose of this investigation is to determine the specific physical and mechanical properties of 11 commercially available soft denture lining materials as a function of accelerated aging. The elastomers chosen for this study are all laboratory-processed lining materials and are marketed for extended service when compared with chairside denture lining materials. The data obtained from exposing these materials to the harsh environment of accelerated aging should provide clinicians with useful information when they are choosing soft denture lining materials for patients.

\section{MATERIAL AND METHODS}

Samples were processed according to the manufacturers' directions, stored in a humidor for 24 hours, then tested for tensile strength, percent elongation, hardness, tear strength, and tear energy before accelerated aging. After these baseline data were obtained, the tests were repeated after a second set of samples were subjected to an accelerated aging chamber (Model 25-WR, Weather-Ometer, Atlas Electric Devices Co., Chicago, Ill.). The weathering cycle was 900 hours of exposure to a xenon ultraviolet/visible light source at $110^{\circ} \mathrm{F}$ and $90 \%$ relative humidity. A programmed cycle of 18 minutes of distilled water spray was used during each 120 minute period. ${ }^{11}$ A sample size of five specimens was used for each material for each test condition. 
Table I. List of materials and manufacturers

\begin{tabular}{|c|c|c|c|}
\hline Material & Type & Batch No. & Company \\
\hline Durasoft & Plasticized polymer or copolymer & 5265 & $\begin{array}{l}\text { Astron Dental } \\
\text { Wheeling, IIl. } 60090\end{array}$ \\
\hline Coe Super & Plasticized polymer or copolymer & $\begin{array}{l}\text { P101089A } \\
\text { L060189A }\end{array}$ & $\begin{array}{l}\text { Coe Company } \\
\text { Chicago, Ill. 60658-1597 }\end{array}$ \\
\hline PróTech & Plasticized polymer or copolymer & $\begin{array}{l}\text { P816894 } \\
\text { L502898 }\end{array}$ & $\begin{array}{l}\text { Pro-Tech, Inc. } \\
\text { Dental Products Division } \\
\text { Centereach, N.Y. } 11720\end{array}$ \\
\hline Justi Soft & Plasticized polymer or copolymer & $\begin{array}{l}\text { P32366 } \\
\text { L320 }\end{array}$ & $\begin{array}{l}\text { Justi Products/American } \\
\text { Tooth Industries } \\
\text { Oxnard, Calif. } 9303\end{array}$ \\
\hline Verno-Soft & Plasticized polymer or copolymer & $\begin{array}{l}\text { P29006 } \\
\text { L092989 }\end{array}$ & $\begin{array}{l}\text { Vernon-Benshoff } \mathrm{Co} \\
\text { Albany, N.Y. } 12201\end{array}$ \\
\hline Velvesoft & Plasticized polymer or copolymer & None & $\begin{array}{l}\text { Oral Health U.S.A., Inc. } \\
\text { Piscataway, N.J. } 08854\end{array}$ \\
\hline Soft-Pak & Plasticized polymer or copolymer & $\begin{array}{l}\text { P359901 } \\
\text { L360901 }\end{array}$ & $\begin{array}{l}\text { General Dental Products } \\
\text { Elk Grove, Ill. } 60007\end{array}$ \\
\hline Flexor & Plasticized polymer or copolymer & 945004 & $\begin{array}{l}\text { Ticonium Co. } \\
\text { Albany, N.Y. } 12201\end{array}$ \\
\hline Prolastic & Silicone & 890301 & $\begin{array}{l}\text { Young Dental } \\
\text { Maryland Heights, Mo. } 63043\end{array}$ \\
\hline Molloplast-B & Silicone & 900103 & $\begin{array}{l}\text { Buffalo Dental Mfg. Co. Inc. } \\
\text { Syosset, N.Y. } 11791\end{array}$ \\
\hline Novus & Polyphosphazene fluoroelastomer & $31489 \mathrm{~A}$ & $\begin{array}{l}\text { Hygenic Corp. } \\
\text { Akron, Ohio } 44310\end{array}$ \\
\hline
\end{tabular}

Tensile specimens were dumbbell shaped as specified in American Society for Testing and Materials (ASTM): 41266 , but modified to provide for a smaller specimen to conserve material. The specimen size was $89 \mathrm{~mm}$ long $\times 3$ $\mathrm{mm} \times 3 \mathrm{~mm}$ in cross section. The specimens were placed in tension in a universal tensile testing machine (Instron Corp., Canton, Mass.) at a strain rate of $50 \mathrm{~cm} /$ minute. Percent elongation values were obtained by attaching an extensometer to the tensile specimen. Hardness was determined with a Shore-A durometer according to ASTM: D2240-64T. The specimen thickness was $1 \mathrm{~cm}$. Tear resistance was determined according to ASTM: D624-54. The notched specimen geometry was that of die $\mathrm{C}$ but modified to provide a smaller sample to conserve material. The strain rate was $50 \mathrm{~cm} /$ minute and the universal testing machine mentioned was used. Tear energy was determined according to Webber et al. ${ }^{12}$ Webber's method of determining tear energy takes into account the highly elastic nature of the elastomer specimens. The tear specimen was $1 \mathrm{~mm}$ thick $\times 25 \mathrm{~mm}$ wide $\times 75 \mathrm{~mm}$ long with a cut down the center. The result was a trouser-shaped specimen. (This test is sometimes referred to as a pantstear test.) The legs of the specimen were bent in opposite directions and stressed with an Instron universal testing machine, which initiates a tear at the end of the cut.

All data were tabulated and statistical comparisons of the means were made by use of a two-way ANOVA and calculated Tukey intervals. ${ }^{13}$ The soft lining materials that were compared are listed according to type and manufacturer in Table $\mathrm{I}$.

\section{RESULTS}

The tensile strength of the soft lining materials ranged from $8.1 \mathrm{~kg} / \mathrm{cm}^{2}$ (unweathered) to $15.9 \mathrm{~kg} / \mathrm{cm}^{2}$ (weathered) for ProTech lining material to $84.9 \mathrm{~kg} / \mathrm{cm}^{2}$ (unweathered) to $88.2 \mathrm{~kg} / \mathrm{cm}^{2}$ (weathered) for Verno-Soft lining material (Fig. 1). Most of the soft lining materials ranged between $25 \mathrm{~kg} / \mathrm{cm}^{2}$ and $56 \mathrm{~kg} / \mathrm{cm}^{2}$ tensile strength for both unweathered and weathered conditions. Most lining materials demonstrated an increase in tensile strength after weathering, with Coe Super Soft, Justi Soft, and Velvesoft lining materials having the greatest increases. Soft-Pak lining material decreased in tensile strength after weathering.

The percent elongation varied between $150 \%$ to $542 \%$ for unweathered specimens and $125 \%$ to $530 \%$ for weathered specimens (Fig. 2). Before and after aging, Verno-Soft lining material had the lowest elongation and Flexor had the highest. The elongation of most lining materials decreased after weathering with the exception of Molloplast-B, which increased from $326 \%$ to $440 \%$.

A wide range of hardness was observed for the soft lining materials. The softest material was Prolastic, which had a Shore-A hardness of 25 units (unweathered) and 30 units (weathered) (Fig. 3). The hardest material was Verno-Soft, with a Shore-A hardness of 95 units for both unweathered 
Tensile Strength and Significant Differences at $p=0.05^{*}$

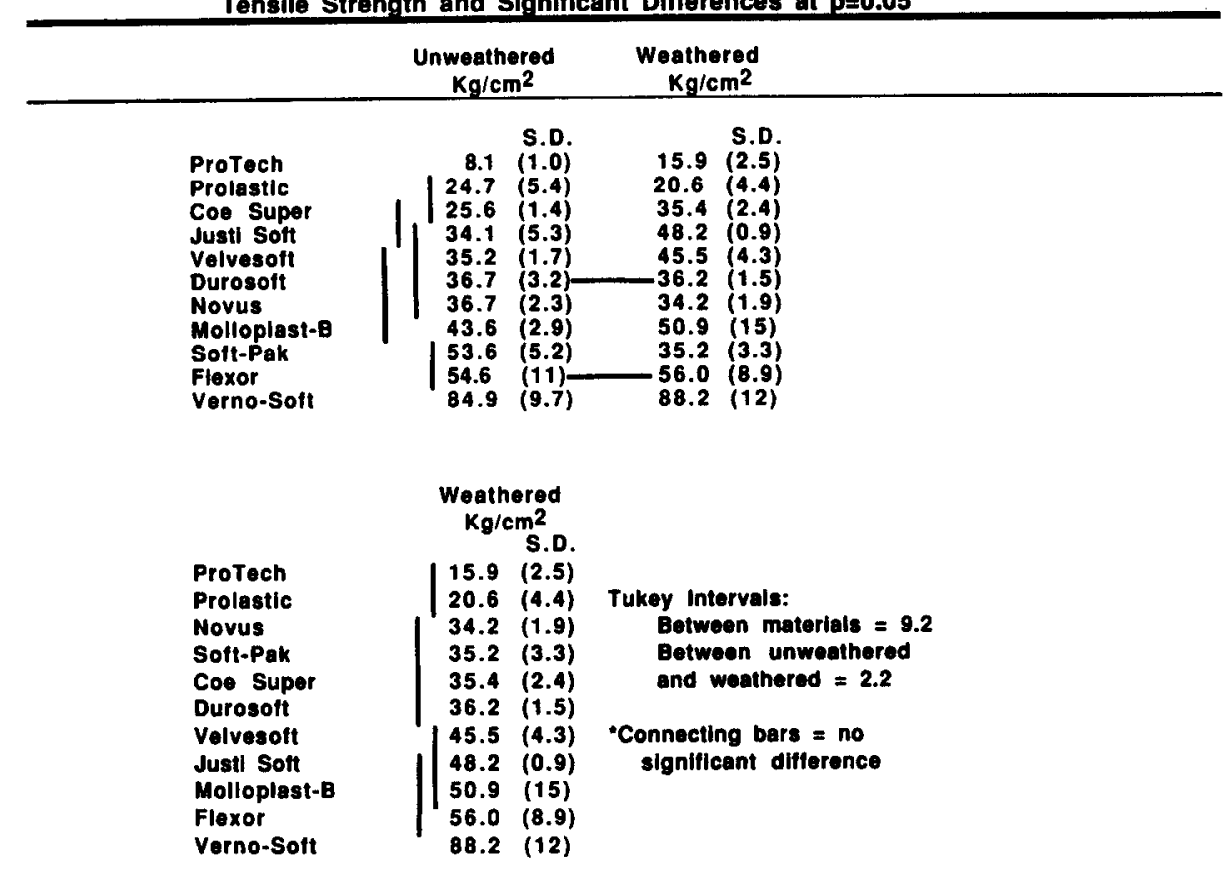

Fig. 1. Tensile strength and significant difference at $p=0.05$.

Percent Elongation and Significant Differences at $p=0.05^{*}$

\begin{tabular}{|c|c|c|c|}
\hline \multirow[b]{2}{*}{$\begin{array}{l}\text { Verno-Soft } \\
\text { Solt-Pak } \\
\text { Coe Super } \\
\text { Novus } \\
\text { Durosoft } \\
\text { Just Soft } \\
\text { Velvesoft } \\
\text { ProToch } \\
\text { Molloplast-B } \\
\text { Protastlc } \\
\text { Flexor }\end{array}$} & \multicolumn{2}{|c|}{$\begin{array}{c}\text { Unweathered } \\
(\%)\end{array}$} & $\begin{array}{c}\text { Weathered } \\
(\%)\end{array}$ \\
\hline & $\begin{array}{r}150 \\
200 \\
232 \\
242 \\
250 \\
250 \\
266 \\
304 \\
326 \\
340 \\
542\end{array}$ & $\begin{array}{l}\text { S.D. } \\
(10) \\
(14)- \\
(13) \\
(16) \\
(31)- \\
(30) \\
(21) \\
(17) \\
(26) \\
(64) \\
(59)\end{array}$ & $\begin{aligned} & S .0 \\
125 & (22) \\
198 & (13) \\
128 & (5) \\
208 & (8) \\
254 & (18) \\
136 & (13) \\
140 & (7) \\
224 & (25) \\
440 & (67) \\
283 & (47) \\
530 & (53)\end{aligned}$ \\
\hline \multicolumn{4}{|c|}{$\begin{array}{c}\text { Weathered } \\
(\%)\end{array}$} \\
\hline $\begin{array}{l}\text { Verno-Solt } \\
\text { Coe Super } \\
\text { Justi Soft } \\
\text { Volvesoft } \\
\text { Soft-Pak } \\
\text { Novus } \\
\text { ProTech } \\
\text { Durosoft } \\
\text { Prolestic } \\
\text { Molloplast-B } \\
\text { Flexor }\end{array}$ & $\begin{array}{l}125 \\
128 \\
136 \\
140 \\
198 \\
208 \\
224 \\
254 \\
293 \\
440 \\
530\end{array}$ & $\begin{array}{l}\text { S.D. } \\
(22) \\
(5) \\
(13) \\
(7) \\
(13) \\
(8) \\
(25) \\
(18) \\
(47) \\
(67) \\
(53)\end{array}$ & $\begin{array}{l}\text { Tukey Intervals: } \\
\text { Botween materials }=48.2 \\
\text { Botween unweathored } \\
\text { and weathered }=11.8 \\
\text { Connecting bars }=\text { no } \\
\text { signiflcant difference }\end{array}$ \\
\hline
\end{tabular}

Fig. 2. Percent elongation and significant difference at $p=0.05$.

and weathered specimens. Soft-Pak, Justi Soft, and Coe Super Soft lining materials also had high hardness values of 80 to 90 Shore-A units. The hardness of Novus, Justi Soft, Soft Pak, and Verno-Soft lining materials remained unchanged after weathering, whereas Molloplast-B and Flexor lining materials were softer. The remaining lining materials all increased in hardness as a function of weathering.

The tear resistance of all lining materials increased as a result of weathering except Prolastic, which decreased from $6.5 \mathrm{~kg} / \mathrm{cm}^{2}$ to $3.7 \mathrm{~kg} / \mathrm{cm}$ and Soft-Pak material, which decreased from $11.7 \mathrm{~kg} / \mathrm{cm}$ to $9.2 \mathrm{~kg} / \mathrm{cm}$ (Fig. 4). Most lin- 
Hardness and Significant Difference at $p=0.05^{*}$

\begin{tabular}{|c|c|c|}
\hline & $\begin{array}{c}\text { Unweathered } \\
\text { (Shore-A) }\end{array}$ & $\begin{array}{l}\text { Weathered } \\
\text { (Shore-A) }\end{array}$ \\
\hline $\begin{array}{l}\text { Prolastic } \\
\text { ProTech } \\
\text { Flexor } \\
\text { Durosoft } \\
\text { Molloplast-B } \\
\text { Novus } \\
\text { Velvesoft } \\
\text { Coe Super } \\
\text { Justl Solt } \\
\text { Soft-Pak } \\
\text { Verno-Solt }\end{array}$ & $\begin{aligned} & \text { S.D. } \\
25 & (1) \\
30 & (2) \\
40 & (2) \\
42 & (1 \\
43 & (2) \\
50 & (1) \\
55 & (2) \\
80 & (2) \\
90 & (1) \\
90 & (1) \\
95 & (2)\end{aligned}$ & $\begin{aligned} & \text { S.D. } \\
30 & (2) \\
38 & (1) \\
35 & (1) \\
55 & (1) \\
35 & (1) \\
-50 & (1) \\
75 & (1) \\
90 & (2) \\
-90 & (2) \\
-90 & (1) \\
-95 & (1)\end{aligned}$ \\
\hline $\begin{array}{l}\text { Prolastic } \\
\text { Flexor } \\
\text { Molloplast-B } \\
\text { ProTech } \\
\text { Novus } \\
\text { Durosoft } \\
\text { Velvesoft } \\
\text { Coe Super } \\
\text { Justt Soft } \\
\text { Soft-Pak } \\
\text { Verno-Solt }\end{array}$ & 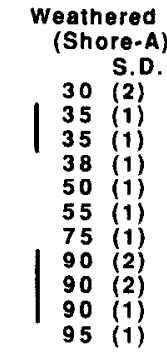 & $\begin{array}{l}\text { Tukey Intervals: } \\
\text { Beiween materials }=2.4 \\
\text { Between unweathered } \\
\text { and weathered }=0.6 \\
\text { "Connecting bers }=\text { no } \\
\text { significant difterence }\end{array}$ \\
\hline
\end{tabular}

Fig. 3. Hardness and significant difference at $p=0.05$.

ing materials had a tear resistance of 7 to $15 \mathrm{~kg} / \mathrm{cm}$ except Verno-Soft, which exceeded all others at $26.3 \mathrm{~kg} / \mathrm{cm}$ (unweathered) and $30.1 \mathrm{~kg} / \mathrm{cm}$ (weathered).

There was a wide range of values for tear energy. Molloplast-B material had the lowest value of $1.4 \mathrm{M} \mathrm{ergs} / \mathrm{cm}^{2}$ (unweathered) and $1.7 \mathrm{M} \mathrm{ergs/} / \mathrm{cm}^{2}$ (weathered) (Fig. 5). Verno-Soft material had the highest tear energy at $40.4 \mathrm{M}$ $\mathrm{ergs} / \mathrm{cm}^{2}$ (unweathered) and $51.7 \mathrm{M} \mathrm{ergs} / \mathrm{cm}^{2}$ (weathered). Most of the lining materials increased in tear energy as a result of weathering.

\section{DISCUSSION}

There was an overlapping of properties, which was expected, between the three different types of soft lining materials. The tensile strength of the silicone lining material was only slightly higher than that of the copolymers. One copolymer (Verno-Soft) surpassed all others in tensile strength $\left(84.9 \mathrm{~kg} / \mathrm{cm}^{2}\right.$ unweathered, $88.2 \mathrm{~kg} / \mathrm{cm}^{2}$ weathered) (Fig. 1). The increase in tensile strength after weathering was probably the result of continued polymerization or loss of plasticizers. This may account for the decrease in percent elongation and the increase in hardness, tear resistance, and tear energy among most of the soft lining materials after weathering.

Both silicone elastomers (Prolastic and Molloplast-B) had high percent elongation (Fig. 2) and lower Shore-A hardness values (Fig. 3) than most of the copolymers and the one polyphosphazene fluoroelastomer. The combination of high percent elongation and low Shore-A hardness value indicates a soft denture lining material. This combi- nation of properties could be used to select a denture lining material with a high degree of softness if the clinician desired this property.

Tear resistance and tear energy values increased after weathering, probably as a result of continued polymerization and/or loss of plasticizers (Figs. 4 and 5). Tear and tensile values provide information on the strength of the denture lining material, but strength values are not sufficient because high bond strength with the denture base material is also required.

Among the copolymers, ProTech lining material had the lowest tensile strength and above average elongation, but it was also one of the softest lining materials. By comparison Verno-Soft material had the highest tensile strength, tear resistance, and tear energy, but it had the lowest elongation. It was the hardest among the copolymers, silicones, and the polyphosphazene. Novus, the only polyphosphazene lining material available on the market at this time, compared favorably with the average properties in all tests.

Because of the extreme range in physical properties between the lining materials tested, no one lining material is superior to all others. If a selection is made on the basis of softness alone, ProTech copolymer or Prolastic silicone materials would be the choices. However, both of these lining materials had low tensile strength, tear resistance, and tear energy. If tear properties are used as a basis for selection, Verno-Soft and Flexor exceed all other lining materials. Verno-Soft material had the highest hardness value of all lining materials tested (95 Shore-A units).

The success or failure of soft lining materials is not de- 
Tear Resistance and Significant Difterence at $p=0.05 *$

\begin{tabular}{|c|c|c|c|c|}
\hline & \multicolumn{2}{|c|}{$\begin{array}{l}\text { Unweathered } \\
(\mathrm{kg} / \mathrm{cm})\end{array}$} & \multicolumn{2}{|c|}{$\begin{array}{l}\text { Weathered } \\
(\mathrm{kg} / \mathrm{cm})\end{array}$} \\
\hline $\begin{array}{l}\text { Protoch } \\
\text { Molloplast-B } \\
\text { Prolastlc } \\
\text { Velvesoft } \\
\text { Coe Super } \\
\text { Just Soft } \\
\text { Novus } \\
\text { Durosoft } \\
\text { Solt-Pak } \\
\text { Flexor } \\
\text { Verno-Soft }\end{array}$ & $\begin{array}{r}2.6 \\
5.4 \\
6.5 \\
6.7 \\
7.1 \\
7.2 \\
8.5 \\
11.2 \\
11.7 \\
13.3 \\
26.3\end{array}$ & $\begin{array}{l}\text { S.D } \\
(0.2) \\
(0.5) \\
(0.7) \\
(0.2) \\
(0.3) \\
(0.4) \\
(0.5) \\
(0.7) \\
(0.7) \\
(1.3) \\
(0.9)\end{array}$ & $\begin{array}{r}3.3 \\
7.9 \\
3.7 \\
12.9 \\
14.9 \\
12.0 \\
14.4 \\
11.8 \\
9.2 \\
14.9 \\
30.1\end{array}$ & $\begin{array}{l}\text { S.D. } \\
(0.5) \\
(0.7) \\
(0.2) \\
(0.7) \\
(0.8) \\
(0.8) \\
(1.3) \\
(0.8) \\
(0.6) \\
(1.6) \\
(1.8)\end{array}$ \\
\hline $\begin{array}{l}\text { ProTech } \\
\text { Prolastic } \\
\text { Molloplast-B } \\
\text { Soft-Pak } \\
\text { Durosoft } \\
\text { Justl Soft } \\
\text { Velvesoft } \\
\text { Novus } \\
\text { Coe Super } \\
\text { Flexor } \\
\text { Verno-Soft }\end{array}$ & $\begin{array}{r}\text { Weatl } \\
\text { (kg) } \\
3.3 \\
3.7 \\
7.9 \\
9.2 \\
11.8 \\
12.0 \\
12.9 \\
14.4 \\
14.9 \\
14.9 \\
30.1\end{array}$ & $\begin{array}{l}\text { ered } \\
\text { cm) } \\
\text { S.D. } \\
(0.5) \\
(0.2) \\
(0.7) \\
(0.6) \\
(0.8) \\
(0.8) \\
(0.7) \\
(1.3) \\
(0.8) \\
(1.6) \\
(1.8)\end{array}$ & \multicolumn{2}{|c|}{$\begin{array}{l}\text { Tukey Intervals: } \\
\text { Between materials }=1.7 \\
\text { Between unweathered } \\
\text { and weathered }=0.3\end{array}$} \\
\hline
\end{tabular}

Fig. 4. Tear resistance and significant difference at $p=0.05$.

Tear Energy and Significant Difference at $p=0.05^{*}$

\begin{tabular}{|c|c|c|c|c|c|}
\hline \multirow[b]{2}{*}{$\begin{array}{l}\text { Prolastic } \\
\text { Floxor } \\
\text { Molloplast-B } \\
\text { ProTech } \\
\text { Duro-Soft } \\
\text { Coo Super } \\
\text { Velvosoft } \\
\text { Soft-Pak } \\
\text { Justl Soft } \\
\text { Novus } \\
\text { Verno-Soft }\end{array}$} & \multicolumn{2}{|c|}{$\begin{array}{l}\text { Unweathered } \\
\text { (M ergs/cm²) }\end{array}$} & \multicolumn{2}{|c|}{$\begin{array}{l}\text { Weathered } \\
\text { (M ergs/cm²) }\end{array}$} & \multirow[b]{2}{*}{$\begin{array}{l}\text { These two matorials do not tonr } \\
\text { but streten as in tonsio elongation. }\end{array}$} \\
\hline & 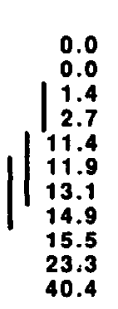 & $\begin{array}{l}\text { S.D. } \\
(0.03)- \\
(0.2) \\
(0.7) \\
(2.3) \\
(1.4) \\
(1.1)- \\
(0.0) \\
(1.6) \\
(6.8)\end{array}$ & $\begin{array}{r}0.0 \\
0.0 \\
-1.7 \\
6.6 \\
14.0 \\
37.8 \\
27.2 \\
-14.3 \\
34.4 \\
16.1 \\
51.7\end{array}$ & $\begin{array}{l}\text { S.D. } \\
(0.01) \\
(0.8) \\
(1) \\
(2.6) \\
(1.9) \\
(2) \\
(1.5) \\
(1.2) \\
(5.5)\end{array}$ & \\
\hline $\begin{array}{l}\text { Prolastle } \\
\text { Flexor } \\
\text { Molloplast-B } \\
\text { ProTech } \\
\text { Duro-Soft } \\
\text { Soft-Pak } \\
\text { Novus } \\
\text { Velvesoft } \\
\text { Justl Soft } \\
\text { Coe Super } \\
\text { Verno-Soft }\end{array}$ & $\begin{array}{r}\text { Weather } \\
\text { (M ergs } \\
0.0 \\
0.0 \\
1.7 \\
6.6 \\
\mid 14.0 \\
14.3 \\
16.1 \\
27.2 \\
34.4 \\
37.8 \\
51.7\end{array}$ & $\begin{array}{l}(0.01) \\
(0.8) \\
(1) \\
(2) \\
(1.2) \\
(1.9) \\
(1.5) \\
(2.6) \\
(5.5)\end{array}$ & & $\begin{array}{l}\text { Akey Int } \\
\text { Betwe } \\
\text { Botw } \\
\text { and }\end{array}$ & $\begin{array}{l}\text { Ivais: } \\
\text { en materials = } 3.2 \\
\text { on unweathered } \\
\text { eathered }=1.0\end{array}$ \\
\hline
\end{tabular}

Fig. 5. Tear energy and significant difference at $p=0.05$.

termined entirely by the physical properties reported in this evaluation. Additional factors are equally important and must be considered. Bond strength between the lining material and denture base must be sufficient to prevent delamination during function. Creep compliance, dynamic modulus, water sorption, and stain resistance are also im- portant factors. In addition, tissue compatibility and the germicidal nature of a lining material are not to be ignored. These factors are being studied.

The range of properties presented in this study indicates the wide choice of materials. The results of this study certainly support the need for a specification for long-term 
soft denture-lining materials. This study and future research may make the task of developing specific criteria possible.

\section{CONCLUSIONS}

1. Accelerated aging dramatically affected the physical and mechanical properties of many of the elastomers.

2. There is a wide range of physical properties for soft denture lining materials.

3. No single soft denture lining material proved to be superior to all others.

4. Essential physical properties required for soft denture lining materials have not been defined and the data obtained in this study would support the development of a specification for soft denture lining materials.

\section{REFERENCES}

1. Lytle RB. The management of abused oral tissues in complete denture construction. J PROSTHET DENT 1957;7:27-42.

2. Lytle RB. Complete denture construction based on a study of the deformation of the underlying soft tissue. J PROSTHET DENT 1959;9:539.

3. Winkler Sheldon, ed. Essentials of complete denture prosthodontics. Philadelphia: WB Saunders Co, 1979;130-3.
4. Boucher CO, Hickey JC, Zarb GA, eds. Prosthodontic treatment for edentulous patients. St. Louis: CV Mosby 1975;37-8.

5. Craig RG, ed. Restorative dental materials. St Louis: CV Mosby, $1989 ; 542-4$

6. Craig RG, Gibbons P. Properties of resilient denture liners. J Am Dent Assoc 1961;63:382-90.

7. Eick JD, Craig RG, Peyton FA. Properties of resilient liners in simulated mouth condition. J PROSTHET DENT 1962;12:1043-52.

8. Council on Dental Research. Resilient liners. J Am Dent Assoc 1963;67:558-62.

9. Gibbons P. Clinical and bacteriologic findings in patients wearing Silastic 390 soft liner. J Mich Dent Assoc, 1965;47:65-7.

10. Wright PS. Composition and properties of soft lining materials for acrylic dentures. J Dent 1981;9:(3)210-23.

11. 1968 Book of ASTM Standards, Part 28. Philadelphia: American, 1968, $1202 \mathrm{pp}$.

12. Webber RL, Ryge G. The determination of tear energy of extensible materials of dental interest. J Biomed Mater Res 1968;2:281-96.

13. Guenther WC. Analysis of variance. Englewood Cliffs, NJ: PrenticeHall, 1964;1-199.

Reprint requests to:

Mn. Edwand R. Dootz

SCHOOL OF DENTTSTRY

UNTVERSITY OF MICHIGAN

ANN ARBOR, MI 48109-1078

\section{Availability of JouRNAL back issues, 1987-1992}

Back issues of The Journal of Prosthetic Dentistry are available for purchase from the publisher, Mosby-Year Book, Inc., at a cost of $\$ 7.50$ per issue. (Foreign postage is not included.) The following quantity discounts are available: $25 \%$ off on quantities of 12 to 23, and one third off on quantities of 24 or more. Please write to Mosby-Year Book, Inc., Subscription Services, 11830 Westline Industrial Drive, St. Louis, MO 63146-3318, or call (800)325-4177, ext. 4351, or (314)453-4351 for information on availability of particular issues for that period from 1987 to 1992. If unavailable from the publisher, photocopies of complete issues are available from University Microforms International, 300 N. Zeeb Rd., Ann Arbor, MI 48106, (313)761-4700. 